\title{
Stakeholders Perception of Teachers Integrity in Elementary Schools in Nigeria
}

\author{
Adebayo, Florence Aduke \\ Department of Educational Foundations and Management, \\ Faculty of Education, Ekiti State University, Ado-Ekiti, Nigeria
}

\begin{abstract}
Elementary school is defined as early childhood care and schooling, free for the Nigerian children. The first 9 years was designed in conformity with the Millennium Development Goals and Education for All (EFA) come 2020. The onus on which the achievement of these goals rest is the teacher who have to maintain high integrity in the performance of its duties effectively and efficiently. These MDS goals may not attain its objectives too without the education stakeholders who are the life wire of educational attainment. Therefore, this study delved into the perception of stakeholders on teacher's integrity in the elementary schools precisely the primary schools in Nigeria. The results showed some adequacies (mastery of subject, job performance, human relation) and inadequacies (usage of ICT, examination malpractice, resourcefulness) on the teacher's integrity. This study therefore, strongly recommended capacity building training and moving from box of coloured chalk to $e$ - teaching for the teachers for improved integrity.
\end{abstract}

\section{Introduction}

The guiding principle of education in Nigeria is equipping of every citizen with such knowledge, skills, attitudes and values as to enable him or her to derive maximum benefits from his or her membership in society, leave a fulfilling life and contribute to the development and welfare of the community. Recently, the spirit of promoting basic education arose to plan to provide every child with a nine - year schooling up to the end of the junior secondary level. This is in line with the No child left behind USA Act of 2001. One of the strategic objectives of the Nigerian vision 2020 is that every child must have opportunity to acquire quality education in an environment conducive to learning. The strategy to be employed will include redesigning the curriculum to sooth the labour market demand and benchmarking of the quality of education standards with global standards and improved teachers knowledge through training and retraining.

In the context of Nigeria, basic education includes early childhood care development and education as well as primary and junior secondary education [4 and 8]. Vis-à-vis in Ghana the neighbouring country, access to basic education lies at the heart of development and lack of educational access and securely acquired knowledge and skill is both a part of the definition of poverty [12].

A school therefore, is an organisation which comprises personnel performing different functions to ensure the attainment of this objective. According to [5], the teacher is one of the prominent and indispensable members of the school organisation team. Since no education system may rise above the quality of its teachers, the National Policy on Education has placed an emphasis on the quality of teachers in terms of qualification, intervention and commitment to teaching to ensure a high productivity [8]. Therefore, the effectiveness of any school depends upon the quality of the teacher delivering the teaching. Brilliant teaching reflects personal integrity and ability to communicate with learners effectively [17].

The teacher is the onus of educational system in any country and the pivot on which all the educational objectives achievement revolve. Therefore, teacher's roles are indispensable and his integrity needs to be addressed for improved teaching and learning process. The teacher as a stakeholder is expected to possess the professional knowledge to lead the pupils in instruction. In addition to serving in an instructional capacity teacher can be a mentor, supervisor, and counsellor and community leader. The role of supervisor is present in every aspect of teacher's daily responsibilities, as a counsellor can be used to offer advice to pupils or students and school advisory committees. The teacher along with the pupils or students plays an interactive role in education process because one cannot function without the other. Therefore, the empowerment of teachers will facilitate the empowerment of the pupils or the students [21].

The end of education have to do with such things as providing the society with a culturallyliterate citizenry, a world class workforce, people who can think and reason [20]. Hence, without teachers, our society would not be able to function as a global competitor. [13] identified top requirement for good teaching to include passion 
and being responsive to students who are consumers of knowledge. A good teacher should be caring, nurturing and developing minds and talents. [17] see teaching as an act and it should be judged for the passion and beauty of the performance and the meaningfulness of the message conveyed. Teaching is a complex and demanding activity which involves mastery of content, classroom control, technique of content, organisation and command to maintain teachers' effectiveness and integrity.

Integrity involves the behaviours and actions consistent with a set of moral or ethical principles and standards embraced by individuals as well as institutions. Academic integrity has been defined as the dignity which an individual exhibits in the pursuit of academic knowledge. [14] viewed integrity as the prestige of oneself in his or her educational endeavours. Therefore, how a teacher conducts himself or herself effectively in a school system is a function of his or her integrity. [12] opined that integrity of a teacher can be evaluated by the education stakeholders. Also, [7] identified the three domains (cognitive, affective and psychomotor) as suitable in assessing teacher's characteristics. The researcher believes that pupils or students are intended beneficiaries of all teachings and therefore are in a unique position to evaluate their teacher's integrity on the job.

[2] identified teacher as one of the challenges facing the early childhood education in Nigeria, hence the need to find out the level of integrity of the teachers to save the Nigerian educational system. In the Nigerian School system teacher's integrity could be measured in terms of qualification, discipline, curriculum, experience and competency [3] but for this study, the researcher is assessing the teacher's integrity from the teacher's mastery of subject, job performance, communication skills, personality and human relationship. The pupils, head-teacher and parents as stakeholders will assess the teachers based on the variables enumerated above. The dependable and in dependable variables used in this study will be reviewed.

\section{Concept of Education Stakeholders}

Education stakeholders are group of people who have vested interest in an action of organisation. It could be an individual or group of people with an interest in the success of an organisation in delivering intended results and maintaining the viability of the organisations products and services. Stakeholders influence programmes products and services. Hence stakeholders are identified as head-teachers, teacher, pupils, parents, parents-teachers association, school management committee, board of governors and Ministry of Education [9].
The roles of education stakeholders are inevitable in the school system. These include an advisory position, developing strategies to train and retrain staff and leaders, turning the academic research into practical points for policy making and international cooperation among countries to promote efficiency of processes and production of reliable leaders, co- training of teachers among sub-African and improve teachers' integrity [6]. Based on these roles the researcher is interested in using the education stakeholders (pupils, headteachers and parents) to assess teachers' integrity.

Teacher Integrity implies the discharge of teaching activities in an open, honest and responsible manner; this is referred to as academic honest [16]. When integrity is related to teaching, a teacher will be maintaining a high level of integrity when he effectively pursues the objectives of education as lay down by the government and also satisfies the needs of the learners and community it supposed to serve. Thus, teachers are supposed to work towards maintenance of institutional integrity while they are at the same time protecting their personal and professional integrity.

[16] stated that academic integrity has suffered at all levels, in all places in Nigeria schools, parents are worried about the quality of discipline among teachers, they are anxious about the outcome of their children's educations. Hence, the researcher delved into the perception of teacher's integrity by the stakeholders to find out probable weaknesses of the teachers. It is obvious, that more and more attention has been paid to the concepts related to teachers' competence at the job and professional integrity. But integrity goes beyond professional integrity. Integrity also deals with behavioural issues that will propel teachers in doing what they should in accordance with the duty of teaching. It is this aspect and others that this study will seek to find.

Parents play key roles as educational stakeholders. Parent's primary objective is the assurance that their children will receive a quality education which enables the children to lead productive rewarding lives as adult in a global society.

The pupil's played a lead role in the educational process and as stakeholders is expected to participate in the process. Successful schools encourage significant participation of parents, pupils and teachers [22].

Job performance is another variable that could determine teacher's integrity. It is the totality of the input of the teacher towards the attainment of educational objectives. It is the act of accomplishing a given task in a school system. It could be measured through the level of teachers competency in subject matter, attendance to lessons, lesson note preparation, content covered, level of coverage of scheme of work, lesson 
preparation, monitoring of pupils work, effective supervision and the disciplinary ability of the teacher.

\section{Statement of the Problem}

Times are changing, as they always do but today these changes are coming to us at a faster rhythm than before, changes on the technological, Climate, intercultural, economic, migration levels and mode of teaching and learning [19]. Nigeria is no exception to this changes which may have influences on the teachers integrity. Observation showed that the problem of teacher's integrity in Nigerian educational system has been a matter of concern to education stakeholders.

The problem of pupils communication and pass their external examinations having being generating argument among the stakeholders. This is in view that, the spill over of these will equally generate problems at the secondary school level vice a vice at the tertiary institutions ending up in the production of incompetent graduates. [15 and 11] seem to support this paper when they opined that different crises with different magnitudes are plaguing educational system in Nigeria. Notable among these are policies instability, improper planning, corruption, implementation of policies, inadequate funding and infrastructural facilities, wastage (repetition and drop-out) and unemployment.

Therefore, of all the crises, those that centre round teachers are significant and worthy of attention because of their valuable roles in the education process and in the translation of carefully prepared education plans into reality at the operational and grassroots levels. Therefore, this paper is interested in using the education stakeholders (pupils, head-teachers and parents) to assess the teachers' integrity in the elementary schools in Nigeria.

The following research questions were generated:

i. What are the perceptions of pupils and headteachers on the mastery of subject matter of the teachers?

ii. What are the perceptions of pupils and headteachers on the job performance of the teachers?

iii. What are the perceptions of pupils and headteachers on the communication skills of the teachers?

iv. What are the perceptions of pupils and headteachers on the personality of the teacher?

v. What are the perceptions of parents and headteachers on the human relations of the teachers?

\section{Research Method}

This study is a descriptive of survey type. The population consists of the elementary schools in six geo-political zones of Nigeria. Purposive random sampling technique was used to select 1000 pupils, 200 head-teachers and 200 parents as education stakeholders from two geo-political zones of Nigeria.

The instrument used was a questionnaire titled 'Perception of Teachers' Integrity (PTI)' for the pupils, head-teachers and the literate parents while interview was used for the illiterate parents by the researcher and the research assistants. The questionnaire was subjected to face content and construct validity. The reliability was 0.82 . The data collected were analysed using Descriptive analysis.

\section{Data Analysis}

Research question 1: What is the perception of pupils, Head-Teacher (HT) on the teacher mastery of subject?

Table 1: Perception of pupils and headteachers on the teacher's mastery of subject matter

\begin{tabular}{|c|l|c|c|c|c|}
\hline \multirow{2}{*}{ S/N } & \multicolumn{1}{|c|}{ Item } & Agree & \multicolumn{3}{|c|}{ Disagree } \\
\cline { 3 - 6 } & Pupils & HT & Pupils & HT \\
\hline 1. & $\begin{array}{l}\text { Effective in } \\
\text { imparting } \\
\text { knowledge }\end{array}$ & 625 & 162 & 375 & 38 \\
\hline 2. & $\begin{array}{l}\text { Good at lesson } \\
\text { delivery }\end{array}$ & 505 & 161 & 495 & 39 \\
\hline 3. & $\begin{array}{l}\text { Effective in } \\
\text { communication }\end{array}$ & 478 & 103 & 522 & 97 \\
\hline 4. & $\begin{array}{l}\text { Mastery of } \\
\text { his/her subject }\end{array}$ & & 161 & & 39 \\
\hline & Mean Average & 536 & 146 & 464 & 54 \\
\hline
\end{tabular}

Research question 2: What is the perception of pupils, Head-Teacher on the teacher mastery of subject?

Table 2: Perception of pupils and headteachers on the teacher's job performance

\begin{tabular}{|c|c|c|c|c|c|}
\hline \multirow[b]{2}{*}{$S / N$} & \multirow[b]{2}{*}{ Item } & Agree & \multicolumn{3}{|c|}{ Disagree } \\
\hline & & Pupils & HT & Pupils & HT \\
\hline 1. & $\begin{array}{l}\text { Regular at } \\
\text { lessons }\end{array}$ & 561 & 125 & 439 & 75 \\
\hline 2. & $\begin{array}{ll}\text { Prepare } & \text { for } \\
\text { lessons } & \\
\end{array}$ & 600 & 112 & 400 & 88 \\
\hline 3. & $\begin{array}{l}\text { Give } \\
\text { assignments and } \\
\text { mark. }\end{array}$ & 860 & 152 & 140 & 48 \\
\hline 4. & $\begin{array}{l}\text { Revise } \\
\text { assignments }\end{array}$ & 970 & 72 & 30 & 28 \\
\hline 5. & $\begin{array}{l}\text { Mark } \\
\text { examination } \\
\text { scripts } \\
\text { punctually }\end{array}$ & & 42 & & 58 \\
\hline
\end{tabular}




\begin{tabular}{|c|c|c|c|c|c|}
\hline 6. & $\begin{array}{l}\text { Keep records } \\
\text { properly, } \\
\text { (Marks books, } \\
\text { attendance } \\
\text { book) }\end{array}$ & & 63 & & 37 \\
\hline 7. & $\begin{array}{l}\text { Resourcefully in } \\
\text { improvisation }\end{array}$ & 495 & 47 & 505 & 53 \\
\hline 8. & $\begin{array}{l}\text { Accept } \\
\text { responsibilities } \\
\text { willingly }\end{array}$ & & 65 & & 35 \\
\hline 9. & $\begin{array}{l}\text { Involve in co- } \\
\text { curricular } \\
\text { activities of the } \\
\text { school }\end{array}$ & & & & \\
\hline & Mean Average & 697 & 129 & 303 & 71 \\
\hline
\end{tabular}

Research question 3: What is the perception of the pupils and head-teachers on communication skills of the teachers?

Table 3: Perception of the pupils and headteachers on communication skills of the teachers' performance

\begin{tabular}{|c|c|c|c|c|c|}
\hline \multirow[b]{2}{*}{$S / N$} & \multirow[b]{2}{*}{ Item } & Agree & \multicolumn{3}{|c|}{ Disagree } \\
\hline & & Pupils & HT & Pupils & HT \\
\hline 1. & $\begin{array}{l}\text { Provision } \\
\text { feedback } \\
\text { students }\end{array}$ & 922 & 183 & 78 & 17 \\
\hline 2. & $\begin{array}{l}\text { Use computer } \\
\text { system to teach }\end{array}$ & & 23 & 923 & 177 \\
\hline 3. & $\begin{array}{l}\text { Use the chalk } \\
\text { board properly }\end{array}$ & 972 & 192 & 28 & 18 \\
\hline 4. & $\begin{array}{l}\text { Listen to } \\
\text { students } \\
\text { questions }\end{array}$ & 467 & 135 & 533 & 65 \\
\hline 5. & $\begin{array}{l}\text { Communicate } \\
\text { with the head- } \\
\text { teacher }\end{array}$ & & 180 & & 20 \\
\hline & Mean Average & 787 & 142 & 213 & 58 \\
\hline
\end{tabular}

Research question 4: What is the perception of the pupils and head-teachers on the teacher's personality?

Table 4: Perception of pupil and headteachers in the personality of the teacher

\begin{tabular}{|c|l|c|c|c|c|}
\hline \multirow{2}{*}{ S/N } & \multicolumn{1}{|c|}{ Item } & Agree & \multicolumn{3}{|c|}{ Disagree } \\
\cline { 3 - 6 } & Pupils & HT & Pupils & HT \\
\hline 1. & Dress decently & 127 & 68 & 73 & 32 \\
\hline 2. & $\begin{array}{l}\text { Have self } \\
\text { control }\end{array}$ & & 133 & & 67 \\
\hline 3. & $\begin{array}{l}\text { Support } \\
\text { examination } \\
\text { malpractice }\end{array}$ & 52 & 185 & 948 & 15 \\
\hline 4. & $\begin{array}{l}\text { Trustworthy } \\
\text { and dependable }\end{array}$ & & 118 & & 82 \\
\hline 5. & Role models & 926 & 183 & 74 & 17 \\
\hline & Mean Average & 489 & 154 & 511 & 46 \\
\hline
\end{tabular}

Research question 5: What is the perception of parents and head-teachers in the human relations of the teachers?

Table 5: Perception of parents and headteachers on the human relations of the

\begin{tabular}{|c|c|c|c|c|c|}
\hline \multirow[b]{2}{*}{$\begin{array}{l}S / \\
N\end{array}$} & \multirow[b]{2}{*}{ Item } & \multirow{2}{*}{$\begin{array}{c}\text { Agree } \\
\text { Paren } \\
\text { ts }\end{array}$} & \multicolumn{3}{|c|}{ Disagree } \\
\hline & & & $\begin{array}{c}\text { Teache } \\
\text { rs }\end{array}$ & $\begin{array}{l}\text { Head- } \\
\text { teache } \\
\text { rs }\end{array}$ & $\begin{array}{c}\text { Paren } \\
\text { ts }\end{array}$ \\
\hline 1 & $\begin{array}{l}\text { Good } \\
\text { rapport } \\
\text { with the } \\
\text { parents }\end{array}$ & 135 & 98 & 102 & 65 \\
\hline 2 & $\begin{array}{l}\text { Good } \\
\text { human } \\
\text { relationshi } \\
\text { p with } \\
\text { colleagues }\end{array}$ & 121 & 103 & 97 & 79 \\
\hline 3 & $\begin{array}{l}\text { Good } \\
\text { relationshi } \\
\text { p with the } \\
\text { pupils }\end{array}$ & 185 & 153 & 47 & 15 \\
\hline 4 & $\begin{array}{l}\text { Give } \\
\text { useful } \\
\text { counsel to } \\
\text { pupils }\end{array}$ & 105 & 172 & 28 & 95 \\
\hline 5. & $\begin{array}{l}\text { Loyal to } \\
\text { the cause } \\
\text { of pupils } \\
\text { performan } \\
\text { ce }\end{array}$ & & 92 & & \\
\hline 6. & $\begin{array}{l}\text { Good } \\
\text { attitude to } \\
\text { sanitation }\end{array}$ & 167 & 153 & 47 & 33 \\
\hline 7. & $\begin{array}{l}\text { Commend } \\
\text { good } \\
\text { performan } \\
\text { ce of } \\
\text { pupils }\end{array}$ & 187 & 108 & 92 & 13 \\
\hline & $\begin{array}{c}\text { Mean } \\
\text { Average }\end{array}$ & 150 & 125 & 75 & 50 \\
\hline
\end{tabular}

Tables 1-5 showed that some of the teachers have mastery of the subject but some were defect in the lesson delivery. No wonder, [10] urged the government to invest on teachers for improved efficiency. Teachers' job performance is above average but defective in resourcefulness and improvisation. The teacher's communication skills seem to be average but defective in the usage of information and communication technology (ICT) to teach the pupils. No wonder, [18] advocated speed training for teachers to move from chalkboard to e-learning and m-learning. Teacher's personality is rated above average except in the area of dress code and support for examination malpractice. This is in line with [1] study that identified examination malpractice as a 
cankerworm that has eaten deep into the fabric of Nigerian educational system and needs to be addressed with stringent measures. However, teachers were adjudged by the parents and headteachers as having good relationship with the entire stakeholders.

\section{Conclusion}

It could be concluded that the teacher's integrity is at stake in the area of examination malpractice and usage of information and communication technology (ICT). However, the teachers' integrity is rated average by the pupils, head-teachers and parents as stakeholders of education in Nigeria.

\section{Recommendations}

Capacity building should be put in place by the government to refresh the teachers on the mastery of the subject based on the area of specialisation. Some states in Nigeria have started on the job training for their teachers to upgrade the teachers. This should be extended to other states.

Teachers should have a rethink on ways of improving on resourcefulness (improvisation of instructional materials) and make the pupils used the materials that are available in their areas.

Usage of information communication technology must be made compulsory in all the schools for effective delivery of lessons since it is globally accepted. Teachers should move from chalkboard to e-teaching.

Examination malpractice is a cankerworm and masquerade in the educational system of the nation. This is being perpetuated by the teachers who are supposed to be role models and builders of the nation, Hence the government should impose severe penalty on the teachers caught in the act of aiding and abetting examination malpractice.

Teachers should maintain the good relationship with the other stakeholders, most importantly, the parents, to produce leaders of tomorrow so as to have a virile nation.

\section{References}

[1] Adebayo, F.A. Towards effective management of examination malpractices in Nigerian schools. Journal of Contemporary Issues. 2004, 2(1): 177-184.

[2] Adebayo, F.A. Early childhood education in Nigeria: Implications for educational manager. London International Conference on Education 2012 Proceedings, London, UK. 2012.

[3] Adeyemi, T.O. (2012). Teacher's quality and internal efficiency in primary schools in Ekiti State, Nigeria. Scientific and Academic Publishing: American Journal of Economics. 2(5); 87-95. E-ISSN: 2166 496X. Retrieved 16/03/2013.

[4]Aviomoh, E.Uko (2007). Universal Basic Education in Nigeria: An appraisal.

www.eric.ed.gov/ERICwebportal. Retrieved 18/03/2013.

[5] Bassey, B.A. and Joshua, M.T. (2004). Teachers' perception of student evaluation of teaching effectiveness. African Education Research Network. www/findarticles.com. Retrieved 21/03/2013.

[6] Brussels Mia Douterlungne (2011). Report of the Conference of the European Network on Education Councils (EUNEC) on participation and stakeholder involvement in education policy making. www.eunec.eu. Retrieved 16/03/2013.

[7]Charles, H. Belanger and Bernard, Longden (2009). The effective teachers' characteristics as perceived by students. European Higher Education Society. ISSN 1573-1936. Retrieved 19/03/2013

[8] Federal Republic of Nigeria. National policy on education, Lagos: Printing Division. Federal Ministry of Information. 2004.

[9] Helle Dossing, Letshego Mokeki, Marinda Weideman (2011). Perception of knowledge of rules and respect among educators: teachers as an indicator of integrity. www.un.org/tisda South Africa. Retrieved 30/03/3013.

[10] Ibukun, W.O. Build the future: Invest in teachers now. Paper presented at the World Teacher Day, held at Akure, Nigeria. 2009.

[11] Ige, A.M. Challenges facing early childhood care, developments and education in an era of Universal Basic Education in Nigeria. Early Childhood Education Journal. 2011, 39(2): 161-167.

[12] Kwane Akyeampong, Jerome Djangmah, Abena Oduro, Ahassan Seiduand \& Frances Hunt (2007). Access to basic education in Ghana: The evidence and the issues. Retrieved 18/03/2013.

[13] LeBlanc, R. (1998). Good teaching: The ten top requirements. www.intranet/committees/guidebook.htm Retrieved 17/03/2013.

[14] Nabukenya, M. (2010). Teachers' perception of the teacher's code of conduct. Retrieved 19/03/2013.

[15] Obanya, P. The dilemma of education in Africa. Ibadan, Nigeria: Heinemann Educational Books PLC. 2004.

[16] Olaseinde-Williams, F.A.O, Abdullahi, O.E. and Owolabi, H.O. The relationship between background variables and cheating tendencies among students of a federal university in Nigeria. Nigeria Journal of Educational Foundations. 2003, 6(1), 64-75.

[17] Olatoye, R.A and Aanu, E. M. Senior secondary school science teachers' perception of using students to evaluate teaching effectiveness. Journal of Emerging 
Trends in Educational Research and Policy Studies (JETERAPS). 2011, 2(3):164-170.

[18] Ormond, Simpson. From box of coloured chalk to power point and beyond. The $12^{\text {th }}$ Cambridge International Conference on Open and Distance Learning. 2007, 56.

[19]Pascal Smet (2010). Challenges of education. www.education Retrieved 15/03/2013.

[20]Schlechty, P.C. (2001). Shaking up the school house: How to support and sustain educational innovation. San Francisco: Jossey-Bass. www.sustainableeducation.org. Retrieved 19/03/2013.

[21]Short, P.M. and Greer, J.T. Leadership in empowered schools. Themes from innovative efforts. Upper Saddle River, NJ: Pearson Education. Retrieved 16/03/2013. 2002.

[22]Wilson, L. Great American schools: The power of culture and passion. Education Digest. 2008, 73(6): 1318. 